\title{
International African Law Association: Symposium in Rome
}

AN international symposium, organized by the Italian section of the International African Law Association, is being held from 24 to 27 March 1971 in Rome at the office of the International Institute for the Unification of Private Law (Oor 84 Roma, Via Panisperna 28). The subject of the symposium is 'The harmonization of private law and of private international law in the commercial fields in western, equatorial and eastern African states', and it is hoped to include a report in a later issue.

\section{Second Annual Congress of Africanists in Germany}

The Association of Africanists in Germany (Vereinigung von Afrikanisten in Deutschland, permanent address : c/o Frau Dr. Brigitta Hennen-Benzing, Johannes GutenbergUniversität, Institut für Ethnologie, 65 Mainz) held its second annual congress at Bortsel near Hamburg from 16 to 19 July 1970 .

Some sixty German Africanists, as well as foreign guests, took part in this congress, which had as its theme: ' Programmatic writings on Africanicity : Senghor's Negro-African Aesthetics and the Arusha Declaration.' Senghor's writings on Négritude and Socialism were analysed by political scientists, literary critics, and linguists. Two linguists presented the first German translation of the original Swahili version of the Arusha Declaration and discussed the specifically African nature of the text. Ethnologists and sociologists considered how far the basic assumptions contained in the Declaration corresponded to African past realities. Political scientists dealt with the effectiveness of the Declaration as a political myth, and economists considered the extent to which it might be effective in mobilizing efforts to develop the Tanzanian economy.

The association consists not only of German scholars, but also of Africanists of other nationalities working in Germany, and is thus open to everyone engaged in scholarly work on Africa in German research institutions. It hopes that all such scholars will join it, enabling it to speak on behalf of African studies in the German Federal Republic, and that, within the context of the federal government's new policy for the establishment of new universities and research institutes, African Studies Institutes will be created at universities where individual Africanists have been engaged in research work and in teaching in the past. The association aims to promote inter-departmental cooperation between the various fields of African Studies in such Institutes.

The theme of the next meeting will be: 'Minority problems on the African continent.' Minorities in this context are understood not in quantitative but in qualitative sociological terms. Not only ethnic minorities in Northern and tropical Africa, but also the black majorities in Southern white-ruled Africa will be considered and the approach to the subject will be determined by the relevance of research for development in Africa and for the German image in Africa, and the need for new scholarly criteria.

The Association hopes that the growing number of members and the research work they accomplish will convince German universities, the Ministries of Education of the Federal States and the Federal Research Association of the need to support African Studies in the Federal Republic of Germany more generously than in the past.

\section{University of Chile Seminar on African Studies}

THE Institute of International Studies of the University of Chile, Santiago, organized within the Afro-Asiatic Studies Group a seminar from 9 September to 4 November 1970 on African subjects for senior students. The topics discussed were: colonialism, nationalism before and after independence, African ideology, military regimes, and African international relations.

(Communicated by Professor Luis Beltrán) 